\title{
Wpływ skażenia zaczynu cementowego płuczką wiertniczą i cieczą buforową na jego wiązanie
}

\section{The effects of cement slurry contamination with the drilling mud and spacer fluid on its setting}

\author{
Miłosz Kędzierski, Marcin Rzepka, Marcin Kremieniewski \\ Instytut Nafty i Gazu - Państwowy Instytut Badawczy
}

\begin{abstract}
STRESZCZENIE: W artykule przedstawiono wyniki badania wpływu skażenia zaczynu cementowego przez płuczkę wiertniczą i ciecz buforową na proces wiązania zaczynu cementowego oraz badania kompatybilności zaczynu cementowego z różnymi rodzajami płuczek wiertniczych. Badania obrazujące proces wiązania zaczynu cementowego skażonego przez płuczkę wiertniczą i ciecz buforową miały na celu określenie wpływu pozostałości z niedokładnie usuniętych cieczy wyprzedzających na parametry powstałego kamienia cementowego, a co się z tym wiąże - na szczelność płaszcza cementowego. W celu przeprowadzenia badań sporządzone zostały mieszaniny zaczynu wytypowanego na podstawie danych otworowych oraz z dodatkiem płuczki bądź cieczy buforowej. Badania zostały podzielone na dwa etapy. Pierwszym etapem było przeprowadzenie przy użyciu aparatu Vicata wstępnych badań czasu wiązania zaczynu uszczelniającego z dodatkiem płuczki wiertniczej oraz cieczy buforowej w ilościach: 10\%, 20\%, 30\% oraz 40\%. Zastosowany podczas uszczelniania kolumny rur 13\%3/8 calowych „czysty” zaczyn cementowy posiadał czas wiązania: 2 godz. 45 min - początek wiązania $(p w)$ oraz 4 godz. - koniec wiązania $(k w)$. Skażenie zaczynu cementowego 10-procentową ilością płuczki wiertniczej spowodowało wydłużenie czasu początku wiązania do 4 godzin, a końca wiązania do 6 godzin. Kolejne ilości dodanej płuczki wiertniczej wydłużały czasy wiązania i przy dodatku 40\% płuczki wiertniczej uzyskano czas początku wiązania wynoszący 11 godzin i czas końca wiązania aż 14 godzin. Dodatek buforu również powodował wydłużenie czasu wiązania, jednak zmiany czasu nie były tak wyraźne. Badania skażenia zaczynu cementowego przez płuczkę wiertniczą wykazały, że zwiększenie ilości procentowej płuczki w wiążącym zaczynie wpływa na pogorszenie parametrów reologicznych zaczynu. W drugim etapie zbadano kompatybilność zaczynu cementowego i płuczki wiertniczej. Podczas prowadzenia badań użyto płuczki polimerowo-potasowej jako płuczki bazowej, następnie zbadano dodatek płuczki glikolowej oraz krzemianowej. Na podstawie badań zauważalne jest obniżenie lepkości plastycznej oraz podniesienie się wartości granicy płynięcia wraz ze wzrostem skażenia zaczynu wszystkimi płuczkami wiertniczymi.
\end{abstract}

Słowa kluczowe: cementowanie otworu wiertniczego, właściwości reologiczne, czas wiązania, zaczyn cementowy, skażenie zaczynu cementowego.

ABSTRACT: The article presents the results of investigation of the effects of cement slurry contamination with drilling mud and spacer fluid on the setting time and the testing of cement slurry compatibility with various types of drilling mud. The studies showing the setting of cement slurry contaminated with drilling mud and spacer fluid were aimed at determining the impact of residues from inaccurately removed spacers or preflushes on the parameters of cement stone and tightness of cement sheath. In order to carry out the tests, mixtures of cement slurry selected on the basis of the borehole data and the addition of mud and spacer fluid were prepared. The tests were divided into two stages. The first one consisted in the preliminary testing of the setting time of cement slurry with the addition of drilling mud and spacer fluid using the Vicat apparatus in quantities: 10\%, 20\%,30\%, and 40\%. The setting time of "clean" cement slurry used in sealing of the 13\%/" casing column was as follows: initial setting time (IST) - 2 hours and 45 minutes, final setting time -4 hours (FST). Contamination of the cement slurry with $10 \%$ of drilling mud resulted in the elongation of the initial setting time to 4 hours, and the final setting time to 6 hours. Subsequent quantities of added drilling mud prolonged setting times and when $40 \%$ of the drilling mud was added, the initial setting time amounted 11 hours, while final setting time - to 14 hours. Addition of the spacer fluid also resulted in a longer setting time, but the time changes were not as pronounced. Investigations on the contamination of cement slurry with a drilling mud showed that the increase in the percentage of mud in the binding slurry results in the deterioration of the rheological parameters of the cement slurry. In the second stage, the compatibility of cement slurry and drilling mud was examined. During the studies, a polymer - potassium mud was used as a base mud, then the addition of glycol mud and silicate mud was examined. The studies show a decrease in plastic viscosity and an increase in the yield point concurrent with an increase in cement slurry contamination with all drilling muds.

Key words: borehole cementing, rheological properties, setting time, cement slurry, cement slurry contamination.

Autor do korespondencji: M. Kędzierski, e-mail: milosz.kedzierski@inig.pl

Artykuł nadesłano do Redakcji 14.05.2019 r. Zatwierdzono do druku 08.10.2019 r. 


\section{Wstęp}

W wielu otworach wykonywanych w rejonie na przedgórzu Karpat oraz w Karpatach bardzo częstym problemem jest występowanie migracji i ekshalacji gazowych (Zima, 2014). Przyczyniają się do tego przede wszystkim skomplikowana budowa geologiczna danego rejonu oraz płytko zalegające horyzonty gazonośne, występujące głównie w utworach miocenu autochtonicznego. Ponadto złoża gazu ziemnego zakumulowane są w słabo zwięzłych warstwach piaskowcowych laminowanych utworami ilastymi. Rejestrowane przez aparaturę kontrolno-pomiarową wskazania gazowe, które są potwierdzone pomiarami geofizycznymi, dowodzą ich występowania zarówno w seriach piaszczystych, jak i ilastych już od głębokości 20-40 m, tuż pod utworami czwartorzędu. Problemy migracji gazu dotyczą głównie zakresu głębokości do ok. $600 \mathrm{~m}$, ponieważ migracja z większych głębokości, zwłaszcza z interwałów izolowanych kolumną rur 7-calowych, występuje sporadycznie (Zima, 2014).

Podczas wykonywania otworów wiertniczych najważniejsze jest zapewnienie szczelności w przestrzeni pierścieniowej. Zaczyn cementowy działa jako uszczelnienie, zapewniając stabilność formacji geologicznych i chroniąc kolumnę rur okładzinowych przed korozją (Soares et al., 2015). Nieudane cementowanie może spowodować zmiany w czasie wiązania cementu i wytrzymałości na ściskanie, co może mieć katastrofalne skutki, takie jak wypadek w Zatoce Meksykańskiej w 2010 r. (Mangadlao et al., 2015). W trakcie cementowania otworu wiertniczego może pojawić się wiele problemów, takich jak kanałowanie cementu i awarie sprzętu (Aughenbaugh et al., 2014). Jednym z problemów występujących podczas cementowania otworów wiertniczych jest brak zgodności reologicznej pomiędzy zaczynem cementowym a płuczką wiertniczą. W związku z tym przeprowadza się testy zgodności, które pomagają w wyborze najbardziej odpowiednich cieczy wiertniczych. Aby uniknąć tworzenia się niepożądanej mieszaniny płuczki wiertniczej i zaczynu cementowego, która powoduje pogorszenie się właściwości cementu, stosuje się ciecze przemywające i buforowe (Nelson i Guillot, 2006; Soares et al., 2017). Są one wtłaczane przed zaczynem cementowym w celu usunięcia płuczki wiertniczej i osadu filtracyjnego dla zwiększenia przyczepności cementu z rurami okładzinowymi i formacją skalną.

Otwory dowiercane do warstw gazonośnych powinny charakteryzować się szczególną szczelnością płaszcza cementowego (Zima, 2014). W przypadku wystąpienia nieszczelności gaz z przestrzeni międzyrurowych należy odpuszczać, ponieważ ciśnienie w górnej części otworu może wzrastać do niebezpiecznych wartości, nawet do ciśnienia złożowego. Niekorzystnym zjawiskiem jest też gaz migrujący wzdłuż otworu, który może przedostawać się do gruntu lub wód gruntowych, oraz gaz przepływający z warstw gazonośnych o dużym ciśnieniu do warstw przepuszczalnych o niskim ciśnieniu, powodujący międzystrefowe rozszczelnienie otworu (Uliasz, 2012; Zima, 2014). Dokładne wyparcie płuczki przez ciecz przemywającą i bufor podczas zabiegu cementowania jest konieczne w celu wyeliminowania pionowego przepływu gazu w przestrzeni pierścieniowej między kolumnami rur oraz poza nimi (Kremieniewski et al., 2018).

\section{Wybrane zagadnienia dotyczące migracji gazu w rejonie Przeworska}

Ekshalacje gazowe w rejonie złoża Przeworsk i samego Przeworska powiązane są z występowaniem migracji na obszarze zapadliska przedkarpackiego. Wiąże się to z budową geologiczną złóż gazu ziemnego w utworach mioceńskich, które charakteryzują się występowaniem pułapek strukturalno-litologicznych typu warstwowego. Utwory czwartorzędowe posiadają zazwyczaj miąższość kilkudziesięciu metrów, co powoduje, iż najwyżej położone warstwy sarmatu są słabo zwięzłe. Dzięki temu warunki do migracji gazu wzdłuż naturalnych powierzchni dyslokacyjnych oraz w strefach otworów wiertniczych w najwyżej zalegających wkładkach piaskowcowych i mułowcowych sarmatu są wręcz idealne. Zjawisko migracji gazu w pewnym stopniu jest procesem naturalnym, wynikającym z faktu, iż przypowierzchniowe utwory sarmatu, charakteryzujące się zmiennym zapiaszczeniem, wykazują znaczną przepuszczalność zarówno wzdłuż uławicenia, jak też w kierunku do niego prostopadłym (Uliasz, 2012).

Występowanie migracji gazu w rejonie złoża Przeworsk ma związek z budową geologiczną horyzontów gazonośnych zlokalizowanych w obrębie utworów piaskowcowo-mułowcowych izolowanych osadami ilastymi. Problemy migracji gazu podczas zabiegu cementowania rur okładzinowych i po zabiegu cementowania pojawiały się bardzo często w rejonie złoża Przeworsk (Herman, 2005; Kremieniewski, 2011).

Objawami ekshalacji gazu często bywa wzrost ciśnienia gazu i wypływ w przestrzeniach międzyrurowych lub też podwyższenie koncentracji składników węglowodorowych w warstwach przypowierzchniowych sąsiadujących przy otworach wiertniczych (Świdziński, 1965). Migracje w przestrzeniach rurowych i pozarurowych mogą skutkować utratą mechanicznej integralności odwiertu.

Wynikiem niekontrolowanej migracji gazu w przestrzeni międzyrurowej (pierścieniowej) lub pozarurowej mogą być:

- erupcje płynu złożowego oraz możliwość wystąpienia pożaru;

- przepływy gazu wewnątrz poziomów gazonośnych, które podnoszą ciśnienia złożowe stref ,zasilanych” gazem migrującym z niższych poziomów, wskutek czego zmianie ulegnie wielkość produkcji oraz zaburzone zostaną warunki w sąsiednich otworach wiertniczych, 
- deformacje rur okładzinowych;

- zanieczyszczenia stref zbiornikowych wody pitnej;

- zagrożenia wybuchem pomieszczeń zamkniętych (studnie, piwnice);

- korozja rur okładzinowych;

- zanieczyszczenia środowiska (Dudek et al., 2004; Zima, 2014).

Analizując czynniki nieskutecznego uszczelnienia przestrzeni pierścieniowych i pozarurowych w otworach wierconych na złożu Przeworsk, nie można wyróżnić jednej przyczyny wypływu gazu, lecz typuje się grupy czynników, które mogą powodować wystąpienie tego zjawiska. Są to czynniki:

- geologiczne - w skład których wchodzi budowa geologiczna rozpatrywanego rejonu, rozkład ciśnień porowych i szczelinowania w profilu otworu, cechy petrofizyczne ośrodka skalnego, rodzaje płynów złożowych, warstw przepuszczalnych, temperatura, warunki hydrogeologiczne, występowanie zaburzeń tektonicznych itp.;

- techniczne - jakość rur okładzinowych i stan ich powierzchni zewnętrznej, szczelność połączeń gwintowych, uzbrojenie kolumny rur, możliwości techniczne i sprawność sprzętu cementacyjnego i aparatury kontrolno-pomiarowej itd.;

- technologiczne - do których zalicza się konstrukcję otworu, powierzchnię poprzecznego przekroju przestrzeni pierścieniowej, stan techniczny i przygotowanie otworu do rurowania i cementowania, ewentualne komplikacje podczas wiercenia, rurowania i cementowania otworu, centryczność kolumn rur w otworze, rodzaje i parametry płuczek wiertniczych (charakterystyka osadu filtracyjnego), skład, objętość, sposób sporządzania i parametry zaczynów cementowych, charakter przepływu podczas ich wytłaczania, poruszanie i obracanie kolumną rur podczas cementowania, ciśnienia wywierane w otworze i przestrzeni międzyrurowej po ukończeniu cementowania;

- mechaniczne - udary i wibracje świdra oraz przewodu wiertniczego podczas zwiercania korka cementowego, buta i dalszego wiercenia, perforacja rur, zmiany ciśnienia w otworze podczas wykonywania opróbowań i zabiegów stymulacyjnych;

- organizacyjne - w skład których wchodzą projekty rurowania i cementowania (zakres wykorzystania informacji geofizycznych, geologicznych i wiertniczych przy ich opracowywaniu), zgodność wykonawstwa zabiegu cementowania z projektem i ewentualne komplikacje, czynności po cementowaniu, wyposażenie zaplecza laboratoryjnego, przygotowanie teoretyczne i zawodowe służby cementacyjnej (Herman, 2005).

Ze względu na dużą liczbę czynników wpływających na skuteczność uszczelniania rur okładzinowych problematyka związana z zapobieganiem migracji gazu jest mocno rozbudowana. Jednak pomimo wielu możliwości wpływania gazu do przestrzeni pierścieniowej warunki konieczne do zaistnienia tego zjawiska są zawsze podobne. Głównym czynnikiem przechodzenia gazu do warstwy zaczynu uszczelniającego jest obniżenie się ciśnienia hydrostatycznego zaczynu uszczelniającego poniżej wartości ciśnienia złożowego w strefie gazonośnej. Drugim warunkiem jest powstawanie dróg migracji gazu w obrębie zaczynu cementowego na jego kontakcie z rurami okładzinowymi lub ze skałą (Kremieniewski i Rzepka, 2016).

Migracja gazu w przestrzeni pierścieniowej oraz pozarurowej poprzez obniżenie się ciśnienia hydrostatycznego zaczynu uszczelniającego jest związana z jego transformacją z fazy ciekłej przez żelową do stanu stałego (kamienia cementowego). W pierwszym etapie, kiedy zaczyn znajduje się w fazie płynnej, ciśnienie hydrostatyczne słupa zaczynu cementowego jest przekazywane na ścianę otworu. Następnie zaczyn ulega żelowaniu, rozpoczyna się budowanie statycznej wytrzymałości strukturalnej i następuje redukcja ciśnienia hydrostatycznego słupa zaczynu cementowego do wartości ciśnienia hydrostatycznego wody zarobowej. Gdy ciśnienie hydrostatyczne słupa wody zarobowej obniży się poniżej wartości ciśnienia złożowego poziomu gazonośnego, to nastąpi wtargnięcie gazu do przestrzeni pierścieniowej. Migracja gazu przez wiążący zaczyn uszczelniający jest możliwa do czasu, aż zaczyn osiągnie wartość wytrzymałości strukturalnej uniemożliwiającą dalszy przepływ gazu przez zaczyn. Minimalna wartość wytrzymałości strukturalnej, która uniemożliwia przechodzenie gazu przez zaczyn, określona jest doświadczalnie i wynosi 240 Pa (Zima, 2014; Kremieniewski i Rzepka, 2016).

Ponadto po wytłoczeniu zaczynu cementowego poza kolumnę rur okładzinowych zachodzą procesy, które mogą się przyczynić do wystąpienia migracji gazu w przestrzeni pierścieniowej. Należy tu wymienić między innymi:

- zastosowanie zaczynu o niewłaściwej gęstości, powodującego zachwianie równowagi hydrostatycznej w przestrzeni pierścieniowej i w konsekwencji migrację gazu przez strukturę wiążącego zaczynu uszczelniającego;

- niedostateczne wyparcie płuczki wiertniczej oraz słabe usunięcie osadu filtracyjnego, powodujące powstawanie kanalików dla migrującego gazu. Zjawisko takie może występować szczególnie w przypadku niecentrycznego ułożenia kolumn rur okładzinowych w otworze, a także w przypadku nieodpowiedniej prędkości tłoczenia zaczynu uszczelniającego i niedokładnego wypłukania otworu przed zabiegiem cementowania (Herman i Migdał, 1998; Kremieniewski, 2016);

- za szybkie wiązania (żelowanie) cementu mogące przyczynić się do powstawania nieciągłości kamienia cementowego, wskutek czego powstają drogi migracji gazu; 
- zbyt wysoką filtrację zaczynu cementowego mogącą spowodować obniżenie objętości zaczynu, w wyniku czego powstaje przestrzeń do której może wnikać gaz i obniżyć ciśnienie hydrostatyczne w kolumnie zaczynu uszczelniającego;

- wysoką przepuszczalność zaczynu uszczelniającego oraz powstałego kamienia cementowego sprzyjającą powstawaniu nieciągłości, którymi może przechodzić gaz;

- nadmierny skurcz kamienia cementowego powodujący powstawanie naprężeń, spękań i wolnych przestrzeni. Często też kamień cementowy odkleja się od rur okładzinowych i skały, a w miejscu pęknięć powstają drogi migracji gazu;

- niszczenie kamienia cementowego w otworze pod wpływem naprężeń wywołanych przez oddziaływanie górotworu powodujących powstawanie dróg migracji gazu;

- brak związania kamienia cementowego ze skałami łupkowo-ilastymi i rurami okładzinowymi powleczonymi środkami ochronnymi przed korozją (Herman i Migdał, 1998; Kremieniewski, 2016).

Z analizy zabiegów uszczelniania kolumn rur, które od strony technicznej prowadzone były prawidłowo, wynika, że na stopień uszczelnienia otworu ma wpływ rodzaj zastosowanej płuczki, jej właściwości inhibitacyjne oraz skład i rodzaj wykorzystanej cieczy przemywającej i zaczynu uszczelniającego. Na podstawie prowadzonych badań stwierdza się, że jakość i ilość pozostawionego na ścianie osadu filtracyjnego decyduje o efektywności uszczelniania kolumny rur. Aby zminimalizować przyczyny powstawania migracji gazu należy:

- wykonać analizę warunków geologiczno-złożowych i właściwości dotychczas stosowanych systemów cieczy wiertniczych w czasie wiercenia i cementowania otworów;

- opracować i dobrać płuczki wiertnicze, których głównym zadaniem będzie takie zabezpieczenie skał ilasto-łupkowych, aby zatłoczona ciecz przemywająca (bufor, przemywka) oraz zaczyn cementowy nie powodowały dalszej ich hydratacji;

- opracować i dobrać ciecze przemywające pod kątem ich korzystnego oddziaływania na ścianę otworu i efektywnego usuwania osadu filtracyjnego;

- opracować i dobrać zaczyny cementowe dla danej kolumny rur okładzinowych zapewniające szczelność cementowanej przestrzeni i uniemożliwiające przepływ cieczy i gazu;

- opracować i dobrać metody skutecznego usuwania osadu filtracyjnego (Zima, 2014; Uliasz et al., 2015).

\section{Metodyka badań}

Badania procesu wiązania zaczynu skażonego dodatkiem płuczki wiertniczej i cieczy buforowej miały na celu określenie wpływu tych cieczy na zmianę (pogorszenie) właściwości
Tabela 1. Proporcje mieszanin zaczynu cementowego i cieczy wyprzedzających

Table 1. Proportions of mixtures of cement slurry and spacer or pre-flush fluids

\begin{tabular}{|c|l|c|}
\hline $\begin{array}{c}\text { Badanie } \\
\text { przy } \\
\text { użyciu }\end{array}$ & \multicolumn{1}{|c|}{ Rodzaj cieczy } & $\begin{array}{c}\text { Proporcje } \\
\text { mieszanin } \\
{[\%]}\end{array}$ \\
\hline \hline \multirow{4}{*}{$\begin{array}{c}\text { Aparat } \\
\text { Vicata }\end{array}$} & Zaczyn cementowy (bazowy) & 100 \\
\cline { 2 - 3 } & Zaczyn cementowy/płuczka wiertnicza & $90 / 10$ \\
\cline { 2 - 3 } & Zaczyn cementowy/płuczka wiertnicza & $80 / 20$ \\
\cline { 2 - 3 } & Zaczyn cementowy/płuczka wiertnicza & $70 / 30$ \\
\cline { 2 - 3 } & Zaczyn cementowy/płuczka wiertnicza & $60 / 40$ \\
\cline { 2 - 3 } & Zaczyn cementowy/bufor & $90 / 10$ \\
\cline { 2 - 3 } & Zaczyn cementowy/bufor & $80 / 20$ \\
\cline { 2 - 3 } & Zaczyn cementowy/bufor & $70 / 30$ \\
\cline { 2 - 3 } & Zaczyn cementowy/bufor & $60 / 40$ \\
\hline
\end{tabular}

zaczynu cementowego. W celu przeprowadzenia badań sporządzone zostały mieszaniny zaczynu wytypowanego na podstawie danych otworowych oraz dodatku płuczki bądź cieczy buforowej. Sporządzone proporcje mieszanin przedstawiono w tabeli 1. Badania zostały podzielone na dwa etapy, w pierwszym określony był czas wiązania, natomiast w kolejnym etapie badano proces wiązania. Dla proporcji mieszanin wytypowanych do pierwszego etapu przeprowadzono badania czasu wiązania przy użyciu aparatu Vicata, dzięki czemu wstępnie określony został początek oraz koniec wiązania.

\section{Badania laboratoryjne i wyniki}

Na podstawie analizy wyników badań zaczynów cementowych otworów P-17 oraz P-18 do dalszych badań wytypowane zostały ciecze wiertnicze otworu P-18. Pierwszym etapem było przeprowadzenie przy użyciu aparatu Vicata wstępnych badań czasu wiązania zaczynu uszczelniającego z dodatkiem płuczki wiertniczej oraz cieczy buforowej w ilościach: $10 \%, 20 \%, 30 \%$, oraz 40\%. Do badań czasu wiązania zaczynu cementowego zastosowanego podczas cementowania kolumny rur w otworze P-18 użyto cieczy buforowej i zaczynu cementowego o składach widocznych w tabeli 2. Wyniki badań przedstawiono w tabeli $2 \mathrm{a}$.

Zastosowany podczas uszczelniania kolumny rur $13 \% 8^{\prime \prime}$ „czysty” zaczyn cementowy posiadał czas wiązania: 2 godz. 45 min - początek wiązania $(p w)$ oraz 4 godz. - koniec wiązania $(k w)$. Skażenie zaczynu cementowego 10-procentową ilością płuczki wiertniczej spowodowało wydłużenie czasu początku wiązania do 4 godzin, a końca wiązania do 6 godzin. Kolejne ilości dodanej płuczki wiertniczej wydłużały czasy wiązania i przy dodatku 40\% płuczki wiertniczej uzyskano 
czas początku wiązania wynoszący 11 godzin, natomiast końca wiązania - 14 godzin.

Dodanie buforu również prowadziło do wydłużenia czasu wiązania, jednak zmiany czasu nie były tak wyraźne. Dodatek $10 \%$ buforu spowodował wydłużenie czasu końca wiązania o 45 minut, natomiast maksymalna z badanych, 40-procentowa ilość buforu w cemencie prowadziła do wydłużenia czasu końca wiązania o 2 godz. 30 minut w stosunku do zaczynu bazowego. Zmiany czasu wiązania zaczynu cementowego skażonego cieczami wyprzedzającymi przedstawiono na rysunku 1.

Podczas uszczelniania kolumny rur 95/8" zastosowano dwa zaczyny cementowe: górny (lekki) oraz dolny o „normalnej” gęstości, na których również przeprowadzone zostały badania czasu wiązania zaczynu cementowego skażonego dodatkiem cieczy wyprzedzających. Dla zaczynu pierwszego (lekkiego), o składzie przedstawionym w tabeli 3 , badania czasu wiązania wykonano, skażając zaczyn dodatkiem płuczki wiertniczej oraz buforu, natomiast w przypadku zaczynu drugiego (o „normalnej” gęstości), o składzie znajdującym się w tabeli 4, nie uwzględniano skażenia buforem, ponieważ nie styka się on bezpośrednio z ,drugim” cementem w trakcie wtłaczania go do otworu.

Pierwszy zaczyn cementowy osiągnął początek wiązania po 9 godzinach, a koniec wiązania po 10 godz. $30 \mathrm{~min}$. Dodanie do tego zaczynu 10-procentowej ilości płuczki wiertniczej spowodowało wydłużenie czasu początku wiązania do

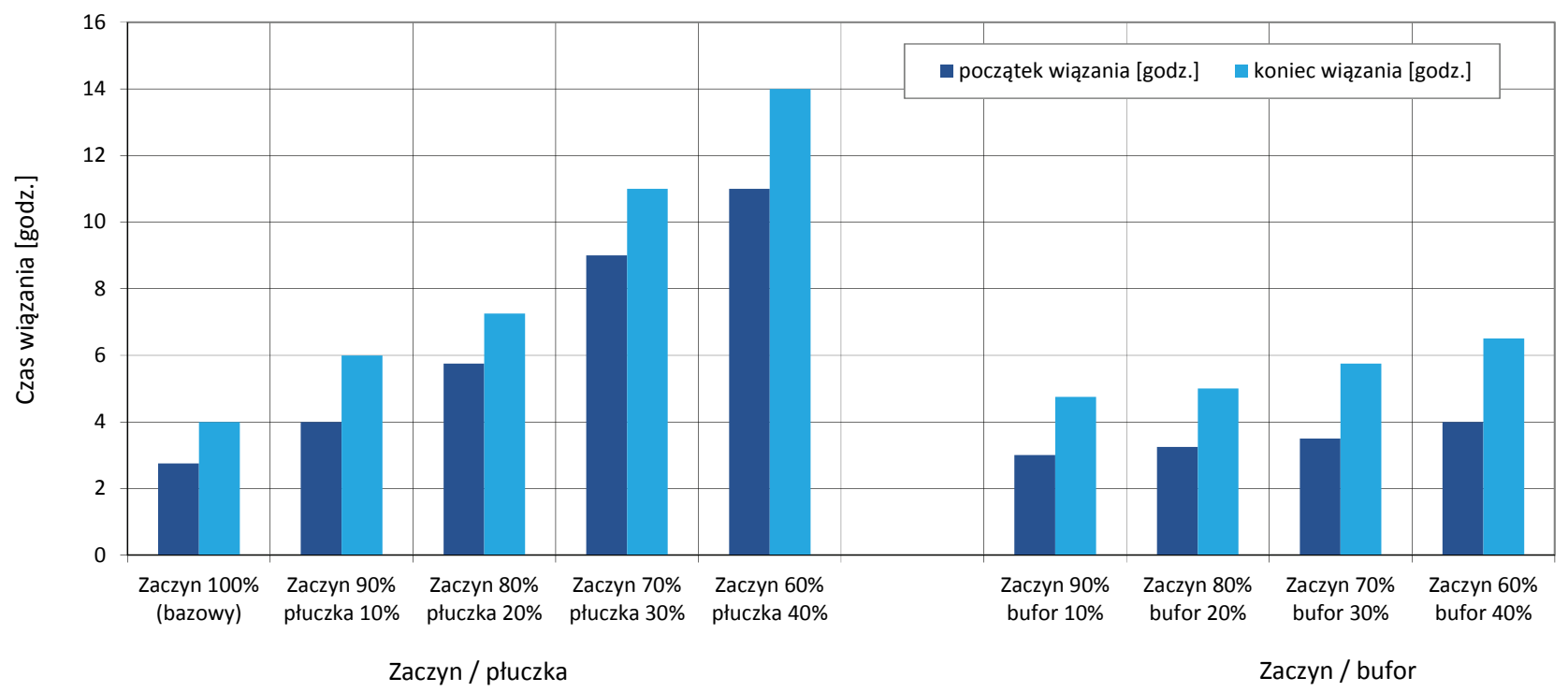

Rys. 1. Czas wiązania zaczynu cementowego skażonego płuczką wiertniczą i cieczą buforową (P-18, rury 13\%3/8)

Fig. 1. Setting time of cement slurry contaminated with drilling mud and spacer fluid (P-18, casing 13\%3")

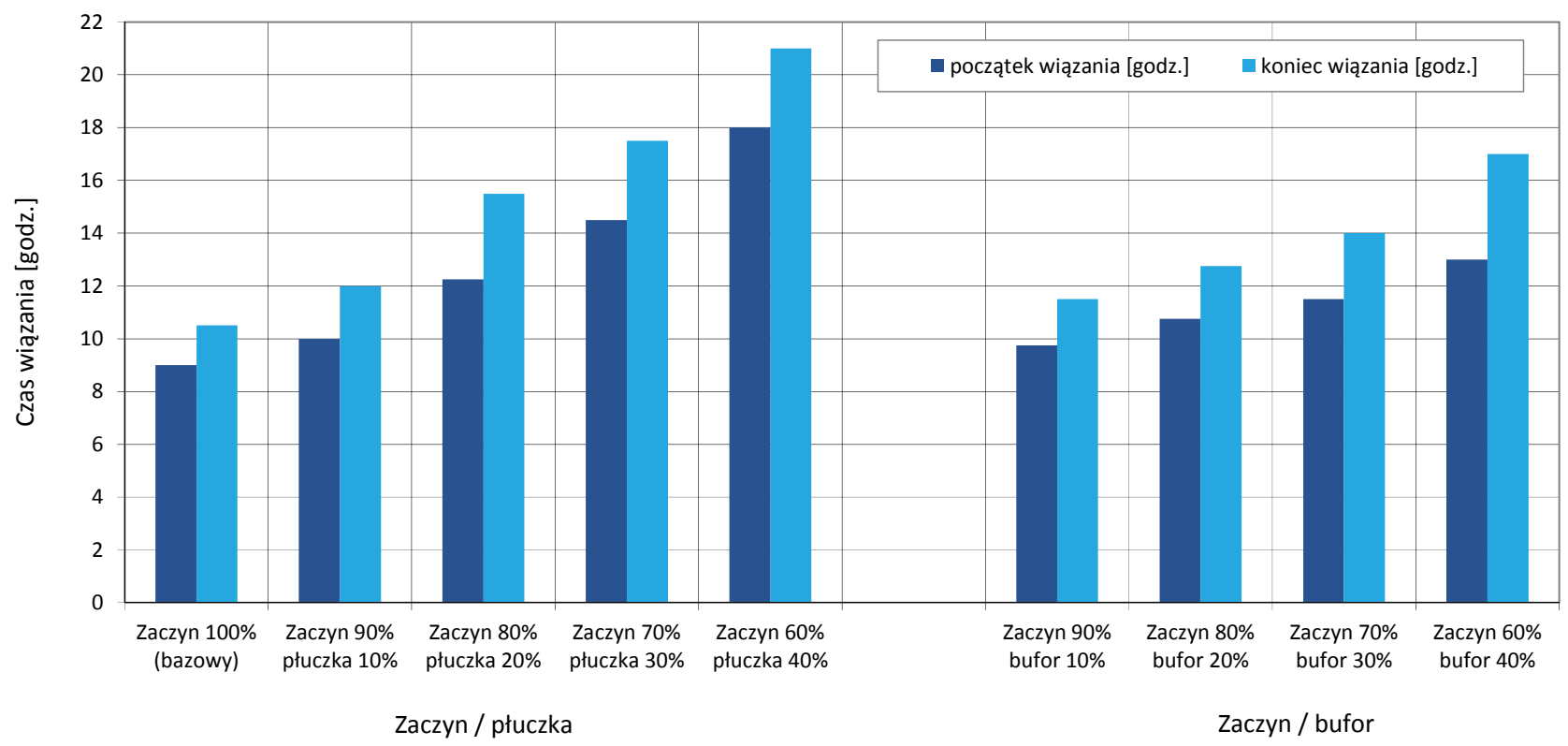

Rys. 2. Czas wiązania zaczynu cementowego skażonego płuczką wiertniczą i cieczą buforową (P-18, rury 95/8", zaczyn I)

Fig. 2. Setting time of cement slurry contaminated with drilling mud and spacer fluid (P-18 casing 95/8", cement slurry I) 
10 godz. i czasu końca wiązania do 12 godz. Przy maksymalnej, 40-procentowej ilości dodatku płuczki czas początku wiązania wydłużył się do 18 godzin, a koniec wiązania odnotowano po 21 godzinach.

Również dodatek buforu cementowego spowodował wydłużenie czasu wiązania o prawie godzinę w stosunku do zaczynu bazowego przy zastosowaniu $10 \%$ buforu. Natomiast wprowadzenie 40-procentowej ilości buforu do zaczynu skutkowało wydłużeniem czasu końca wiązania o 6,5 godziny w porównaniu do zaczynu bazowego. Wyniki badań przedstawione zostały na rysunku 2 oraz w tabeli 3 .

Drugi zaczyn cementowy, o „normalnej” gęstości, uzyskał początek wiązania po czasie 4 godzin, natomiast koniec wiązania odnotowano 30 minut później. Dodatek 10\% płuczki wiertniczej do tego zaczynu spowodował wydłużenie czasu początku wiązania tylko o 15 minut oraz wydłużenie czasu końca wiązania o 30 minut. Większe ilości dodawanej płuczki również zwiększały czas początku wiązania. Dodatek $30 \%$ płuczki wydłużył czas początku wiązania o godzinę w stosunku do zaczynu bazowego (bez dodatku płuczki). Koniec wiązania w tym przypadku odnotowano po czasie o 5 godzin dłuższym od uzyskanego dla zaczynu bazowego. Po dodaniu do zaczynu $40 \%$ płuczki początek wiązania odnotowano po 9 godz. $30 \mathrm{~min}$, natomiast koniec wiązania po ponad 13 godzinach. Wyniki badań przedstawiono na rysunku 3 oraz w tabeli 4.

Tabela 2. Zaczyn cementowy dla otworu P-18, cementowanie rur $133 / 8^{\prime \prime}$. Temperatura $25^{\circ} \mathrm{C}$

Table 2. Cement slurry for P-18 borehole, cementing of 133/8" pipes. Temperature $25^{\circ} \mathrm{C}$

\section{$\underline{1 . S k ł a d ~ z a c z y n u}$}

Woda z wiertni

$\mathrm{w} / \mathrm{c}=0,53$

$\mathrm{KCl}$ (bwow)

$3,0 \%$

Dodatek odpieniający

$0,3 \%$

Dodatek upłynniający

$0,2 \%$

Dodatek regulujący czas gęstnienia $\quad 2,0 \%$

Dodatek przeciwmigracyjny

$8,0 \%$

Mikrocement

$20,0 \%$

Cement CEM I 32,5R

$100 \%$

Dodatek spęczniający

$0,3 \%$

Gęstość

$1,81 \mathrm{~g} / \mathrm{cm}^{3}$

\section{Bufor}

Woda $-100 \%, \mathrm{KCl}-3 \%$ bwow, cement CEM I 32,5R

3. Płuczka otworowa (bentonitowa)
Tabela 2a. Wyniki badań wiązania zaczynu skażonego płuczką i buforem

Table 2a. The results of setting time of cement slurry contaminated with mud and spacer fluid

\begin{tabular}{|l|c|c|}
\hline \multicolumn{1}{|c|}{ Rodzaj cieczy } & $\begin{array}{c}\text { Początek } \\
\text { wiązania }\end{array}$ & $\begin{array}{c}\text { Koniec } \\
\text { wiązania }\end{array}$ \\
\cline { 2 - 3 } [h:min] & [h:min] \\
\hline \hline $\begin{array}{l}\text { Zaczyn cementowy - 100\% } \\
\text { (bazowy) }\end{array}$ & $2: 45$ & $4: 00$ \\
\hline $\begin{array}{l}\text { Zaczyn cementowy - 90\% } \\
\text { Płuczka wiertnicza - 10\% }\end{array}$ & $4: 00$ & $6: 00$ \\
\hline $\begin{array}{l}\text { Zaczyn cementowy - 80\% } \\
\text { Płuczka wiertnicza - 20\% }\end{array}$ & $5: 45$ & $7: 15$ \\
\hline $\begin{array}{l}\text { Zaczyn cementowy - 70\% } \\
\text { Płuczka wiertnicza - 30\% }\end{array}$ & $9: 00$ & $11: 00$ \\
\hline $\begin{array}{l}\text { Zaczyn cementowy - 60\% } \\
\text { Płuczka wiertnicza - 40\% }\end{array}$ & $11: 00$ & $14: 00$ \\
\hline $\begin{array}{l}\text { Zaczyn cementowy - 90\% } \\
\text { Bufor - 10\% }\end{array}$ & $3: 00$ & $4: 45$ \\
\hline $\begin{array}{l}\text { Zaczyn cementowy - 80\% } \\
\text { Bufor - 20\% }\end{array}$ & $3: 15$ & $5: 00$ \\
\hline $\begin{array}{l}\text { Zaczyn cementowy - 70\% } \\
\text { Bufor - 30\% }\end{array}$ & $3: 30$ & $5: 45$ \\
\hline $\begin{array}{l}\text { Zaczyn cementowy - 60\% } \\
\text { Bufor - 40\% }\end{array}$ & $4: 00$ & $6: 30$ \\
\hline
\end{tabular}

Podczas prowadzenia badań użyto płuczki polimerowo-potasowej jako płuczki bazowej, następnie zbadano dodatek płuczki glikolowej oraz krzemianowej. Dla powyższych mieszanin wykonane zostały również badania kompatybilności zaczynu cementowego i użytej płuczki wiertniczej. W tabeli 5 zestawiono wyniki badań kompatybilności pierwszego zaczynu 
Tablica 3. Zaczyn cementowy dla otworu P-18, cementowanie rur $95 / 8^{\prime \prime}$. Temperatura $30^{\circ} \mathrm{C}$

Table 3. Cement slurry for P-18 borehole, cementing of $95 / 8$ " pipes. Temperature $30^{\circ} \mathrm{C}$

\section{Skład zaczynu I}

Woda z wiertni

$\mathrm{KCl}$ (bwow)

Dodatek odpieniający

Dodatek upłynniający

Dodatek antyfiltracyjny

Dodatek przeciwmigracyjny

Mikrocement

Mikrosfery

Cement CEM I 32,5R

Dodatek spęczniający

Gęstość

$\mathrm{w} / \mathrm{c}=0,55$
$3,0 \%$
$0,5 \%$
$0,2 \%$
$0,2 \%$
$8,0 \%$
$20,0 \%$
$8,0 \%$
$100 \%$
$0,3 \%$
$1,63 \mathrm{~g} / \mathrm{cm}^{3}$

2. Bufor

Woda - 100\%, $\mathrm{KCl}-3 \%$ bwow, cement CEM I 32,5R

\section{Płuczka otworowa (polimerowo-potasowa)}

Tabela 3a. Wyniki badań wiązania zaczynu skażonego płuczką i buforem

Table 3a. The results of setting time of cement slurry contaminated with mud and spacer fluid

\begin{tabular}{|l|c|c|}
\hline \multicolumn{1}{|c|}{ Rodzaj cieczy } & $\begin{array}{c}\text { Początek } \\
\text { wiązania }\end{array}$ & $\begin{array}{c}\text { Koniec } \\
\text { wiązania }\end{array}$ \\
\cline { 2 - 3 } [h:min] & h:min] \\
\hline \hline $\begin{array}{l}\text { Zaczyn cementowy - 100\% } \\
\text { (bazowy) }\end{array}$ & $9: 00$ & $10: 30$ \\
\hline $\begin{array}{l}\text { Zaczyn cementowy - 90\% } \\
\text { Płuczka wiertnicza - 10\% }\end{array}$ & $10: 00$ & $12: 00$ \\
\hline $\begin{array}{l}\text { Zaczyn cementowy - 80\% } \\
\text { Płuczka wiertnicza-20\% }\end{array}$ & $12: 15$ & $15: 30$ \\
\hline $\begin{array}{l}\text { Zaczyn cementowy - 70\% } \\
\text { Płuczka wiertnicza - 30\% }\end{array}$ & $14: 30$ & $17: 30$ \\
\hline $\begin{array}{l}\text { Zaczyn cementowy - 60\% } \\
\text { Płuczka wiertnicza - 40\% }\end{array}$ & $18: 00$ & $21: 00$ \\
\hline $\begin{array}{l}\text { Zaczyn cementowy - 90\% } \\
\text { Bufor - 10\% }\end{array}$ & $9: 45$ & $11: 30$ \\
\hline $\begin{array}{l}\text { Zaczyn cementowy - 80\% } \\
\text { Bufor - 20\% }\end{array}$ & $10: 45$ & $12: 45$ \\
\hline $\begin{array}{l}\text { Zaczyn cementowy - 70\% } \\
\text { Bufor - 30\% }\end{array}$ & $11: 30$ & $14: 00$ \\
\hline $\begin{array}{l}\text { Zaczyn cementowy - 60\% } \\
\text { Bufor - 40\% }\end{array}$ & $13: 00$ & $17: 00$ \\
\hline
\end{tabular}

zastosowanego podczas cementowania kolumn rur 95/8" otworu P-18. Zauważalne jest obniżenie lepkości plastycznej oraz podniesienie się wartości granicy płynięcia wraz ze wzrostem skażenia zaczynu wszystkimi płuczkami wiertniczymi.
Tabela 4. Zaczyn cementowy dla otworu P-18, cementowanie rur $95 / 8^{\prime \prime}$. Temperatura $30^{\circ} \mathrm{C}$

Table 4. Cement slurry for P-18 borehole, cementing of $95 / 8^{\prime \prime}$ pipes. Temperature $30^{\circ} \mathrm{C}$

\section{Skład zaczynu II}

$\begin{array}{ll}\text { Woda z wiertni } & \mathrm{w} / \mathrm{c}=0,53 \\ \mathrm{KCl} \text { (bwow) } & 3,0 \% \\ \text { Dodatek odpieniający } & 0,3 \% \\ \text { Dodatek upłynniający } & 0,2 \% \\ \text { Dodatek przeciwmigracyjny } & 8,0 \% \\ \text { Mikrocement } & 20,0 \% \\ \text { Cement CEM I 32,5R } & 100 \% \\ \text { Dodatek spęczniający } & 0,3 \% \\ \text { Gęstość } & 1,81 \mathrm{~g} / \mathrm{cm}^{3}\end{array}$

2. Płuczka otworowa (polimerowo-potasowa)

Tabela 4a. Wyniki badań wiązania zaczynu skażonego płuczką Table 4a. The results of setting time of cement slurry contaminated with mud

\begin{tabular}{|l|c|c|}
\hline \multicolumn{1}{|c|}{ Rodzaj cieczy } & $\begin{array}{c}\text { Początek } \\
\text { wiązania }\end{array}$ & $\begin{array}{c}\text { Koniec } \\
\text { wiązania }\end{array}$ \\
\cline { 2 - 3 } [h:min] & [h:min] \\
\hline \hline $\begin{array}{l}\text { Zaczyn cementowy }-100 \% \\
\text { (bazowy) }\end{array}$ & $4: 00$ & $4: 30$ \\
\hline $\begin{array}{l}\text { Zaczyn cementowy - 90\% } \\
\text { Płuczka wiertnicza }-10 \%\end{array}$ & $4: 15$ & $5: 00$ \\
\hline $\begin{array}{l}\text { Zaczyn cementowy - } 80 \% \\
\text { Płuczka wiertnicza - } 20 \%\end{array}$ & $4: 30$ & $7: 00$ \\
\hline $\begin{array}{l}\text { Zaczyn cementowy - 70\% } \\
\text { Płuczka wiertnicza }-30 \%\end{array}$ & $5: 00$ & $9: 30$ \\
\hline $\begin{array}{l}\text { Zaczyn cementowy }-60 \% \\
\text { Płuczka wiertnicza }-40 \%\end{array}$ & $9: 30$ & $13: 30$ \\
\hline
\end{tabular}

\section{Podsumowanie i wnioski}

1. Problematyka zapobiegania zjawisku migracji gazu jest skomplikowana i wymaga przeanalizowania wielu czynników mających wpływ na jakość cementowania.

2. Na skuteczność cementowania wpływa prawidłowo opracowany projekt oraz przeprowadzony zabieg cementowania, jednak już na etapie wiercenia otworu można przyczynić się do poprawy szczelności cementowania poprzez odpowiedni dobór składu i właściwości cieczy wiertniczych. Rozpoznanie zjawisk zachodzących na kontakcie skała-płuczka wiertnicza, a następnie skała-ciecz przemywająca i skała-zaczyn cementowy umożliwia dobór cieczy wiertniczych do zabiegu cementowania zapewniających poprawę szczelności pomiędzy skałą a kamieniem 
Tabela 5. Kompatybilność zaczynu cementowego i stosowanych płuczek

Table 5. Compatibility of cement slurry and used muds

\begin{tabular}{|c|c|c|c|c|c|}
\hline \multirow{2}{*}{$\begin{array}{l}\text { Płuczka wiertnicza/ } \\
\text { zaczyn cementowy }\end{array}$} & pl./cem. & pl./cem. & pl./cem. & pl./cem. & pl./cem. \\
\hline & $100 / 0$ & $\mathbf{0} / \mathbf{1 0 0}$ & $5 / 95$ & $10 / 90$ & $20 / 80$ \\
\hline \multicolumn{6}{|c|}{ Płuczka potasowo-polimerowa } \\
\hline $\mathrm{PV}[\mathrm{m} \cdot \mathrm{Pas}]$ & 28 & 162 & 151 & 132 & 98 \\
\hline $\mathrm{YP}[\mathrm{Pa}]$ & 25 & 11 & 36 & 38 & 36 \\
\hline \multicolumn{6}{|c|}{ Płuczka glikolowa } \\
\hline $\mathrm{PV}[\mathrm{m} \cdot \mathrm{Pas}]$ & 30 & 162 & 132 & 109 & 84 \\
\hline $\mathrm{YP}[\mathrm{Pa}]$ & 31 & 11 & 28 & 29 & 23,5 \\
\hline \multicolumn{6}{|c|}{ Płuczka krzemianowa } \\
\hline $\mathrm{PV}[\mathrm{m} \cdot \mathrm{Pas}]$ & 36 & 162 & 148 & 91,5 & 70 \\
\hline $\mathrm{YP}[\mathrm{Pa}]$ & 28 & 11 & 22 & 32 & 28 \\
\hline \multicolumn{6}{|c|}{ Płuczka mrówczanowa } \\
\hline $\mathrm{PV}[\mathrm{m} \cdot \mathrm{Pas}]$ & 26 & 162 & 94 & 88 & 74 \\
\hline $\mathrm{YP}[\mathrm{Pa}]$ & 13 & 11 & 20 & 22 & 26 \\
\hline
\end{tabular}

Objaśnienie skrótów:

PV - lepkość plastyczna

YP - granica płynięcia

cementowym. Poprzez dobór cieczy o odpowiednich właściwościach można $\mathrm{w}$ znacznym stopniu ograniczyć powstawanie dróg migracji gazu na jego kontakcie z rurami okładzinowymi lub ze skałą.

3. Kolejnym zjawiskiem powodującym powstawanie nieszczelności płaszcza cementowego jest przechodzenie gazu do warstwy zaczynu uszczelniającego na skutek obniżenia się ciśnienia hydrostatycznego zaczynu uszczelniającego poniżej wartości ciśnienia złożowego w strefie gazonośnej.

4. Badania skażenia zaczynu cementowego przez płuczkę wiertniczą wykazały, że zwiększenie ilości procentowej płuczki i buforu w zaczynie cementowym wpływa na pogorszenie parametrów reologicznych zaczynu oraz wydłużenie czasu wiązania zaczynu cementowego.

5. Na podstawie badań zauważalne jest obniżenie lepkości plastycznej oraz podniesienie się wartości granicy płynięcia wraz ze wzrostem skażenia zaczynu wszystkimi płuczkami wiertniczymi.

6. Największy spadek lepkości plastycznej zaobserwowano dla płuczki krzemianowej i mrówczanowej.

7. Największy wzrost granicy płynięcia nastąpił dla płuczki potasowo-polimerowej.

Artykuł powstał na podstawie pracy statutowej pt.: Zaczyny cementowe o krótkich czasach żelowania i wiązania do uszczelniania plytkich otworów wiertniczych - praca INiG - PIB na zlecenie MNiSW; nr zlecenia: 0017/KW/2018, nr archiwalny: DK-4100-0017/2018.

\section{Literatura}

Aughenbaugh K., Nair S.D., Cowan K., van Oort E., 2014. Contamination of deepwater well cementations by syntheticbased drilling fluids. Society of Petroleum Engineers. DOI: 10.2118/180325-MS.

Dudek J., Dudek L., Klimek P., 2004. Badania ekshalacji gazu w rejonie złoża Przeworsk. Konferencja Naukowo-Techniczna GEOPETROL, Zakopane 20-23.09.2004, Prace IGNiG, 130: 931-935.

Herman Z., 2005. Problemy migracji i ekshalacji gazu w odwiertach. Technické Univerzity Ostrava, Řada Hornicko-Geologická.

Herman Z., Migdał M., 1998. Problemy cementowania rur okładzinowych na Niżu Polskim. Nafta-Gaz, 12: 542-553.

Kremieniewski M., 2011. Proces migracji gazu w trakcie wiązania zaczynu cementowego. Nafta-Gaz, 3: 175-181.

Kremieniewski M., 2016. Ograniczenie ekshalacji gazu w otworach wiertniczych poprzez modyfikację receptur oraz kształtowanie się struktury stwardniałych zaczynów uszczelniających. Prace Naukowe Instytutu Nafty i Gazu - Państwowego Instytutu Badawczego, 199. DOI: 10.18668/PN2016.199.

Kremieniewski M., Kędzierski M., Rzepka M., 2018. Poprawa oczyszczania przestrzeni pierścieniowej otworu wiertniczego przed zabiegiem cementowania. Prace Naukowe Instytutu Nafty i Gazu - Państwowego Instytutu Badawczego, 220: 1-172. DOI: 10.18668/PN2018.220.

Kremieniewski M., Rzepka M., 2016. Przyczyny i skutki przepływu gazu w zacementowanej przestrzeni pierścieniowej otworu wiertniczego oraz metody zapobiegania temu zjawisku. Nafta-Gaz, 9: 722-728. DOI: 10.18668/NG.2016.09.06.

Mangadlao J.D., Cao P., Advincula R.C., 2015. Smart cements and cement additives for oil and gas operations. Journal of Petroleum Science and Engineering, 129: 63-76.

Nelson E.B., Guillot D., 2006. Well Cementing. Schlumberger, Sugar Land.

Soares L.W.O., Braga R.M., Freitas J.C.O., Ventura R.A., Pereira D.S.S., Melo D.M.A., 2015. The effect of rice husk ash 
as pozzolan in addition to cement Portland Class G for oil well cementing. Journal of Petroleum Science and Engineering, 131: 80-85.

Soares A.A., Freitas J.C.O., Melo D.M.A., Braga R.M., AmaralMachado L., Santos P.H.S., Soares L.W.O., 2017. Cement slurry contamination with oil-based drilling fluids. Journal of Petroleum Science and Engineering, 158: 433-440.

Świdziński H., 1965. Naturalne ekshalacje dwutlenku węgla w Karpatach Wschodnich. Rocznik Polskiego Towarzystwa Geologicznego, 35(4): 417-430.

Uliasz M., 2012. Kompleksowa analiza przyczyn migracji gazu w otworach realizowanych na przedgórzu Karpat i w Karpatach pod kątem właściwości cieczy wiertniczych stosowanych w czasie wiercenia i cementowania kolumn rur okładzinowych. Praca niepublikowana. Archiwum Instytutu Nafty i Gazu - Państwowego Instytutu Badawczego, Kraków, nr zlecenia: 529/KW/11, nr archiwalny: DK-4100-86/11.

Uliasz M., Zima G., Błaż S., Jasiński B., 2015. Ocena właściwości cieczy wiertniczych w aspekcie zapobiegania migracji gazu w otworach na przedgórzu Karpat. Nafta-Gaz, 1: 11-17.

Zima G., 2014. Wpływ właściwości płuczek wiertniczych na jakość cementowania w gazonośnych poziomach miocenu. Nafta-Gaz, 12: 899-907.

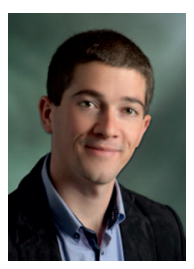

Mgr inż. Miłosz KĘDZIERSKI

Specjalista inżynieryjno-techniczny w Zakładzie

Technologii Wiercenia

Instytut Nafty i Gazu - Państwowy Instytut Badawczy ul. Lubicz 25 A

31-503 Kraków

E-mail:milosz.kedzierski@inig.pl

Dr inż. Marcin RZEPKA
Kierownik Laboratorium Zaczynów Uszczelniających
w Zakładzie Technologii Wiercenia
Instytut Nafty i Gazu - Państwowy Instytut Badawczy
ul. Lubicz 25 A
31-503 Kraków
E-mail: marcin.rzepka@inig.pl

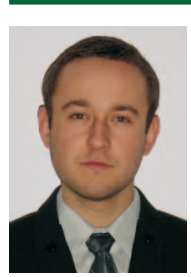

Dr inż. Marcin KREMIENIEWSKI

Adiunkt w Zakładzie Technologii Wiercenia Instytut Nafty i Gazu - Państwowy Instytut Badawczy ul. Lubicz 25 A

31-503 Kraków

E-mail:marcin.kremieniewski@inig.pl

\section{OFERTA}

\section{LABORATORIUM BADAŃ ŚRODOWISKOWYCH}

- badania w zakresie akredytacji nr AB 493:

» pomiary poziomu hatasu na stanowiskach pracy,

» pomiary poziomu hałasu od instalacji lub urządzeń z wyznaczaniem map akustycznych,

» pomiary drgań mechanicznych o dziataniu ogólnym i miejscowym,

» pomiary oświetlenia elektrycznego,

» pomiary zapylenia (frakcja wdychalna i respirabilna, wolna krzemionka);

- badania poza zakresem akredytacji:

» pomiary poziomu hałasu infradźwiękowego, ultradźwiękowego,

» wyznaczanie poziomu mocy akustycznej maszyn i urządzeń,

» organizowanie badań międzylaboratoryjnych w zakresie: drgania ogólne i miejscowe, hałas na stanowiskach pracy, oświetlenie elektryczne.

Laboratorium oganizuje badania międzylaboratoryjne w zakresie: drgania ogólne i miejscowe, hałas na stanowiskach pracy, oświetlenie elektryczne.

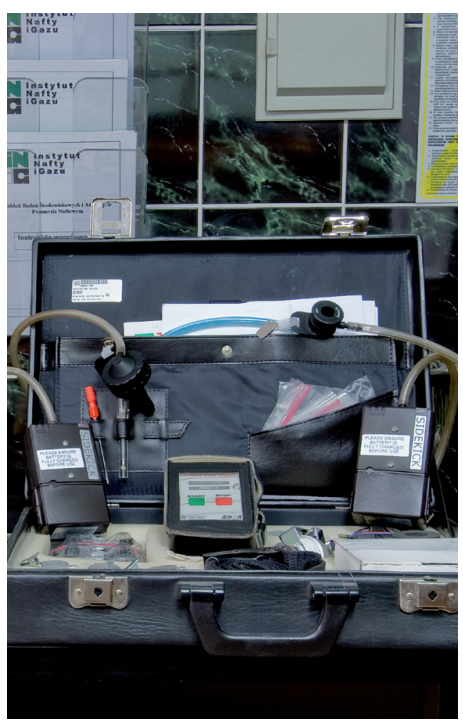

INSTYTUT NAFTY I GAZU

- Państwowy Instytut Badawczy 